Herz 2018 · 43:423-430

https://doi.org/10.1007/s00059-018-4719-x

Published online: 15 June 2018

(c) The Author(s) 2018

CrossMark

\author{
B. Maisch + P. Alter \\ 'Fachbereich Medizin, Philipps-Universität Marburg und Herz- und Gefäßzentrum (HGZ) Marburg, \\ Marburg, Germany \\ ${ }^{2}$ Klinik für Innere Medizin-Pneumologie und Intensivmedizin, UKGM und Philipps-Universität Marburg, \\ Marburg, Germany
}

\title{
Treatment options in myocarditis and inflammatory cardiomyopathy
}

\section{Focus on i.v. immunoglobulins}

In 2012 we reviewed the treatment options in (peri)myocarditis and inflammatory cardiomyopathy in a special issue of this journal devoted to heart failure and cardiomyopathies [1]. Now, 5 years later, it is timely and appropriate to take stock of old and new data on this topic.

\section{Evolution of diagnoses}

In 2013, experts of the European Society of Cardiology (ESC) working group on myocardial and pericardial diseases published a position statement on "The current state of knowledge on aetiology, diagnosis, management and therapy of myocarditis" [2]. Specifically named causes of myocarditis were either infective or immune-mediated or toxic $[2,3]$. - Table 1 sums up the long list of possible causative pathogens and compares them with the real-world data of the Marburg Myocarditis Registry (MMR) comprising records of 1098 biopsied patients with suspected inflammatory dilated cardiomyopathy and/or myocarditis $[1,4]$. The comments add important clues on how the diagnosis was made in the MMR. Not mentioned but self-evident are a full clinical work-up of the patient including a detailed history, electrocardiogram (ECG) at rest and at exercise, imaging by Doppler echocardiography or cardiac magnetic resonance imaging (MRI), as well as a complete laboratory examination with $\mathrm{C}$-reactive protein (CRP) as a marker of inflammation and N-terminal pro-B-type natriuretic peptide (NT-
proBNP) and high-sensitivity (hs) troponin $\mathrm{T}$ or I as cardiac biomarkers of heart failure and necrosis, respectively. Of note, cardiac MRI is an important method for clarifying the presence of inflammation or fibrosis in addition to function and pericardial effusion, but it cannot substitute endomyocardial biopsy for establishing an etiologically based diagnosis [1-5]. For the diagnosis of viral vs. autoreactive (nonviral) myocarditis and for the diagnosis of eosinophilic or giant cell myocarditis, endomyocardial biopsy remains essential, while the biopsy work-up includes histology, immunohistology, and polymerase chain reaction (PCR) for RNA or DNA viruses [1-6].

\section{Special considerations for complex diagnoses}

Whether diabetic cardiomyopathy is a diagnosis of its own is still under discussion. In endomyocardial biopsies of patients with heart failure and diabetes, histology can show microangiopathy, some infiltrating macrophages and leukocytes, and also a positive PCR of viral genomes such as parvovirus B19. Diabetic cardiomyopathy can be part of a syndrome comprising hypertrophy and microangiopathy due to hypertensive heart disease and diabetes and viral persistence [7]. For diagnosis of the underlying etiology, a composite view of the clinical evidence and exclusion of other causes of cardiomyopathy by endomyocardial biopsy can be an important clue. However, behind the curtain of diabetic cardiomyopathy, viral heart disease with or without inflammation can be hidden. But which of the factors is then the major etiological determinant?

This issue also holds true for alcoholic cardiomyopathy [8]. In these patients, alcohol consumption of more than $40 \mathrm{~g} /$ day in men and more than $20 \mathrm{~g} /$ day in women for more than 5 years is the somewhat arbitrary diagnostic determinant for the label of alcoholic cardiomyopathy. In endomyocardial biopsy, some infiltrating leukocytes may even suggest myocarditis in immunocompetent alcohol-dependent individuals as a likely differential diagnosis.

\section{Clinical syndromes associated with inflammatory cardio- myopathy and myocarditis}

Depending on the etiology, genetic predisposition, and comorbidities of the individual patient, at least four clinical syndromes can be identified after coronary artery disease is excluded by angiography (• Fig. 1):

1. Life-threatening heart failure or rhythm disturbance

2. Acute chest wall syndrome with angina pectoris-like symptoms, often after an infection

3. Acute onset of heart failure

4. Chronic heart failure

- Table 2 connects these clinical syndromes with classic textbook diagnoses 

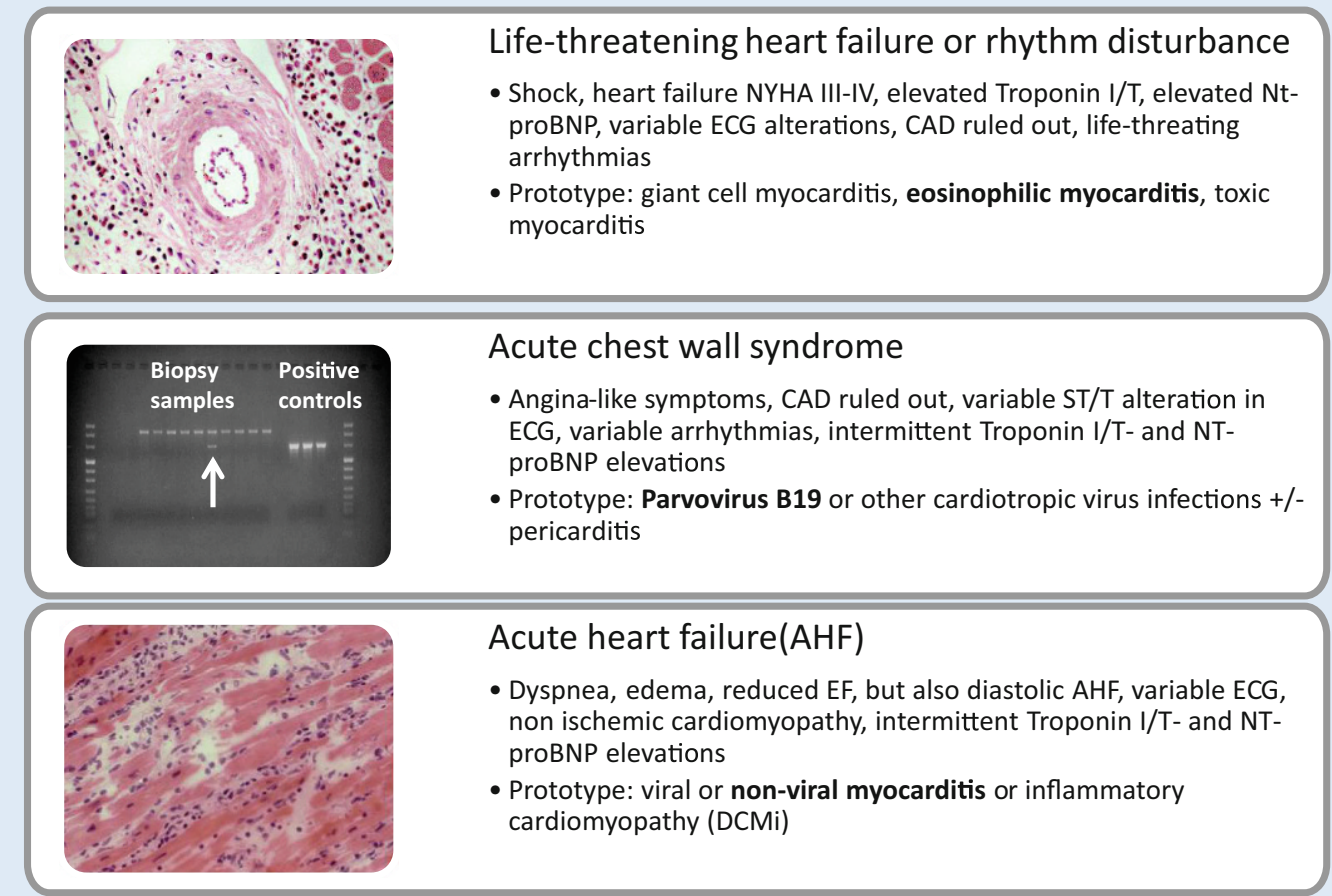

Acute heart failure(AHF)

- Dyspnea, edema, reduced EF, but also diastolic AHF, variable ECG, non ischemic cardiomyopathy, intermittent Troponin I/T- and NTproBNP elevations

- Prototype: viral or non-viral myocarditis or inflammatory cardiomyopathy (DCMi)

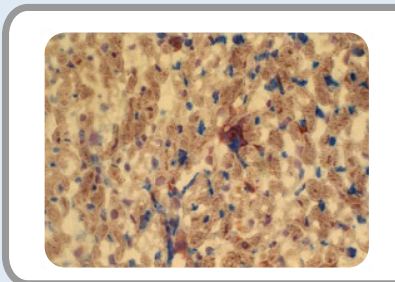

\section{Chronic heart failure(CHF)}

- All CHF symptoms for longer time span, CAD ruled out, ECG with LBBB, RBBB, AV-Block variable ST-/T-alterations, intermittent Troponin I/T-and NT-proBNP elevations

- Prototype: every viral or non-viral(autoreactive) focal myocarditis or DCMi
Fig. $1<$ Clinical and histological phenotypes of myocarditis and inflammatory cardiomyopathy. CAD coronary artery disease, $E C G$ electrocardiogram, $E F$ ejection fraction, $L B B B$ left bundle branch block, NYHA New York Heart Association, $R B B B$ right bundle branch block such as fulminant, acute, chronic, or persistent chronic myocarditis.

\section{Treatment}

\section{Restriction of physical activity}

In suspected or histologically validated myocarditis, restriction of physical activity for at least 6 months is part of the international guidelines. This is highly recommended until the inflammation has disappeared-evidenced by cardiac MRI or endomyocardial biopsy-and cardiac function has normalized.

\section{Heart failure therapy for inflammatory cardiomyopathy}

Heart failure therapy is part of the treatment of inflammatory cardiomyopathy. It was successfully demonstrated in many heart failure trials on angiotensin-converting enzyme (ACE) inhibition such as the CONSENSUS trial with enalapril, the SOLVD trial with captopril, the ATLAS trial with lisinopril, or the HOPE trial with ramipril. In the CHARM and ELITE II trials, angiotensin receptor blockers demonstrated a similar benefit. Today, beta-blockade is part of the therapeutic armamentarium in the treatment of any form of heart failure as demonstrated in the MERIT-HF trial for metoprolol, the CIBIS trial for bisoprolol, and the COPERNICUS trial for carvedilol. In acute cardiac decompensation, loop diuretics are effective and aldosterone receptor blockers should be given on top of the other heart failure drugs as demonstrated by the RALES trials for spironolactone in heart failure and by the EPHESUS trial for eplerenone in heart failure patients after myocardial infarction. According to the findings of the SHIFT trial, ivabradine can be given to treat sinus tachycardia and to reduce heart rate to below $70 \mathrm{bpm}$. Cardiac glycosides were tested in the DIG trial, which demonstrated a reduction of allcause and heart failure-related hospitalization with no change in mortality rate. Their use in patients with tachyarrhythmia reduces heart rate and improves the quality of life.

Antiphlogistic treatment with nonsteroidal anti-inflammatory drugs (NSAIDs) such as ibuprofen or indomethacin should be reserved for patients with pericardial involvement, since in murine coxsackie B3 myocarditis this treatment was shown to be detrimental [12]. For treatment of peri(myo)carditis, we prefer colchicine instead, not only in recurrent forms but also for the first attack [13].

\section{Antiarrhythmic treatment}

Apart from beta-blockers, antiarrhythmic treatments for heart failure and for cardiomyopathy patients have been dis- 
appointing. A meta-analysis of all trials with amiodarone demonstrated a reduction in total mortality of $13 \%$ [14], but the SCD-HeFT trial, in which patients with a single-chamber implantable cardioverter-defibrillator (ICD) were randomized to amiodarone or to placebo, showed a decrease in mortality for the treatment group only [15]. The discussion of whether rate or rhythm control is more beneficial in the treatment of atrial fibrillation is still ongoing. Sufficient anticoagulation is important under all circumstances.

\section{Device therapy}

In patients with dilated cardiomyopathy with or without inflammation, antibradycardia pacing in second- and third-degree atrioventricular block or in bradyarrhythmia is well established. If the ejection fraction (EF) is below 35\% and acute myocarditis is diagnosed, causespecific treatment should be carried out with a LifeVest wearable defibrillator. If inflammation has disappeared and cardiac function remains low $(\mathrm{EF}<35 \%)$, the implantation of an ICD is warranted according to current guidelines [16].

\section{Immunosuppressive treatment}

\section{Idiopathic giant cell myocarditis}

If untreated, the natural course of giant cell myocarditis is fatal in almost all cases [17]. The few patients in the MMR were treated with a combination of prednisone and azathioprine (see autoreactive myocarditis). The maintenance doses of prednisone $(7.5 \mathrm{mg} /$ day $)$ and azathioprine $(50 \mathrm{mg} / \mathrm{day})$ were given as a lifelong therapy. All patients received an ICD and have survived 5 years without heart transplantation.

\section{Cardiac sarcoidosis}

In cardiac sarcoidosis the infiltration of cells including giant cells is confined to the noncaseous granuloma. In the MMR, cardiac sarcoidosis was six times more frequent than giant cell myocarditis. The treatment algorithm is either corticoid therapy alone or in combination with

Herz 2018 · 43:423-430 https://doi.org/10.1007/s00059-018-4719-x

(c) The Author(s) 2018

B. Maisch · P. Alter

\section{Treatment options in myocarditis and inflammatory cardiomyopathy. Focus on i. v. immunoglobulins}

\section{Abstract}

For myocarditis and inflammatory cardiomyopathy, an etiologically driven treatment is today the best option beyond heart failure therapy. Prerequisites for this are noninvasive and invasive biomarkers including endomyocardial biopsy and polymerase chain reaction on cardiotropic agents. Imaging by Doppler echocardiography and cardiac magnetic resonance imaging as well as cardiac biomarkers such as C-reactive protein, $\mathrm{N}$-terminal pro-B-type natriuretic peptide, and troponins can contribute to the clinical work-up of the syndrome but not toward elucidating the underlying cause or pathogenetic process. This review summarizes the phases and clinical features of myocarditis and gives an up-to-date short overview of the current treatment options starting with heart failure and antiarrhythmic therapy. Although inflammation in myocardial disease can resolve spontaneously, often specific treatment directed against the causative agent is required. For fulminant, acute, and chronic autoreactive myocarditis, immunosuppressive treatment has proven to be beneficial in the TIMIC and ESETCID trials; for viral cardiomyopathy and myocarditis, intravenous immunoglobulin lgG subtype and polyvalent intravenous immunoglobulins $\lg G, \lg A$, and $\lg M$ can frequently resolve inflammation. However, despite the elimination of inflammation, the eradication of parvovirus B19 and human herpesvirus- 6 is still a challenge, for which ivlg treatment can become a future key player.

\section{Keywords}

Carditis - Inflammation - Cardiomyopathies . Treatment $\cdot$ Intravenous immunoglobulins

\section{Behandlungsoptionen bei Myokarditis und inflammatorischer Kardiomyopathie. Immunglobuline i.v. im Fokus}

\section{Zusammenfassung}

Bei Myokarditis und inflammatorischer Kardomyopathie ist heute neben der bewährten Behandlung der Herzinsuffizienz eine ätiologisch begründete Therapie die beste Option. Voraussetzungen dafür sind die Bestimmung nichtinvasiver und invasiver Biomarker inklusive Endomyokardbiopsie und Polymerasekettenreaktion (PCR) auf kardiotrope Substanzen. Bildgebende Verfahren wie Echodoppler- und kardiale MRT-Untersuchung sowie kardiale Biomarker wie CRP, NT-proBNP, Troponin können die Diagnostik in Bezug auf das Syndrom ergänzen, zielen aber nicht auf den verursachenden Erreger oder den zugrunde liegenden autoreaktiven Pathomechanismus. Neben den Phasen und dem klinischen Bild der Myokarditis werden kurz die aktuelle Herzinsuffizienzund antiarrhythmische Therapie dargestellt.
Die spontane Rückbildung der Entzündung ist zwar möglich, oft wird aber eine spezifische Therapie erforderlich. Bei fulminanter, akuter und chronischer autoreaktiver Myokarditis hat sich gemäß der TIMIC- und ESETCIDStudie eine immunsuppressive Behandlung als nützlich erwiesen. Bei viraler inflammatorischer Kardiomyopathie und Myokarditis sind i.v.-Immunglobuline (IgG bzw. IgGAM, also polyvalente $\lg G$, IgA und $\lg M$ ) in der Lage, die Entzündung fast immer, die virale Ursache (Parvovirus B19 und humanes Herpesvirus 6, HHV6) bei der überwiegenden Zahl der betroffenen Patienten zu eliminieren.

Schlüsselwörter

Karditis - Inflammation - Kardiomyopathie . Therapie · Intravenöse Immunglobuline other immunosuppressive drugs, e.g., azathioprine or cyclosporine [18].

\section{Eosinophilic heart disease}

Eosinophilic heart disease (EHD) and the resulting endomyocardial fibrosis are rare diseases. Its common pathogenetic denominator is the overproduction of cytotoxic eosinophils [19].

Our experience with long-term prednisone and azathioprine documents a survival rate of 9 out 10 cases over a mean period of 8.4 years [20]. 
Table 1 Causes of myocarditis and inflammatory cardiomyopathy in the MMR

Infectious agent \% pos. Comments

in MMR Diagnosis made via:

1. Infectious myocarditis

Bacteria

Chlamydia pneumoniae

0.03 Serodiagnosis

0.02 IGRA (Quantiferon) or microscopy from sputum, pericardial fluid, in Africa more frequent

Haemophilus influenzae

0.002

Serodiagnosis

Staphylococci

0.03

Blood culture, in sepsis or endocarditis

Streptococci

0.02

Spirochete

Syphilis

0.001

Borrelia burgdorferi

0.7

In rheumatic fever, in cooperation with Chandigarh

\begin{tabular}{|c|c|c|c|}
\hline & Borrelia burgdorferi & 0.7 & $\begin{array}{l}\text { ELISA and Western blot or PCR } \\
\text { from EMB }\end{array}$ \\
\hline Rickettsia & Coxiella burnetiid & 0.005 & $\begin{array}{l}\text { Serodiagnosis, predominant } \\
\text { pericarditis }\end{array}$ \\
\hline Fungi & Candida & 0.002 & $\begin{array}{l}\text { In immunocompromised } \\
\text { patients, diagnosed by culture }\end{array}$ \\
\hline \multirow[t]{2}{*}{ Protozoa } & Plasmodium falciparum (malaria) & 0.002 & Microscopy (thick blood film) \\
\hline & Toxoplasmagondii & 0.002 & Serodiagnosis \\
\hline $\begin{array}{l}\text { Helminthic infec- } \\
\text { tions }\end{array}$ & - & 0 & None in MMR \\
\hline \multicolumn{4}{|c|}{ Viruses (RNA subtype) } \\
\hline \multirow[t]{3}{*}{ Picornaviruses } & Coxsackie A + B & 0.019 & $\begin{array}{l}\text { All by PCR, epidemiologic } \\
\text { shift in late 1990s, none since } \\
2002\end{array}$ \\
\hline & Echo & 0.005 & PCR \\
\hline & Hepatitis B and C & 0.002 & Serodiagnosis or PCR \\
\hline \multirow[t]{2}{*}{ Orthomyxoviruses } & Influenza A or B & 0.002 & Serodiagnosis \\
\hline & H1N1 & 0.001 & Serodiagnosis \\
\hline \multirow[t]{2}{*}{ Paramyxoviruses } & Mumps & 0.001 & Serodiagnosis \\
\hline & Measles & 0.002 & Serodiagnosis \\
\hline Toga-/Rubivirus & Rubella & 0.001 & Serodiagnosis \\
\hline Flavi-/Arbovirus & Dengue & 0.001 & Serodiagnosis \\
\hline \multicolumn{4}{|c|}{ Viruses (DNA subtype) } \\
\hline Adenoviruses & $A 1,2,3,5$ & 0.011 & PCR \\
\hline \multirow[t]{7}{*}{ Erythroviruses } & Parvovirus B19 types $1-3$ & 28 & PCR \\
\hline & $\begin{array}{l}\text { Herpesviruses: human herpes } \\
6 \text { virus }\end{array}$ & 0.03 & $\begin{array}{l}\text { PCR; sometimes together with } \\
\text { PVB } 19 \text { virus }\end{array}$ \\
\hline & Cytomegalovirus & 0.02 & PCR or ISH \\
\hline & Epstein-Barr virus & 0.012 & PCR \\
\hline & Varicella zoster & 0.001 & Serodiagnosis \\
\hline & Retrovirus: HIV & 0.005 & PCR or by serodiagnosis \\
\hline & Rhabdovirus & 0.001 & - \\
\hline
\end{tabular}

Treatment in autoreactive, lymphocytic myocarditis

\section{Immunosuppression}

No randomized or blinded treatment trials have been published in the past 6 years with respect to immunosuppressive therapy in myocarditis.

Viral infection, according to common belief, may trigger an autoreactive cellular and humoral immune response that leads to myocardial damage with inflam- mation. Following this pathogenetic hypothesis, immunosuppressive treatment either by prednisone alone or in combination with azathioprine or cyclosporine was examined in five trials, the results of which are summarized in $\bullet$ Table 3 .

The first randomized, placebo-controlled trial on prednisone in myocarditis was conducted by Parillo et al. [21], who treated 60 patients with inflammation and 62 without inflammation out of a dilated cardiomyopathy cohort of 122 patients with prednisone: $67 \%$ of the patients with inflammation who received prednisone and $28 \%$ of inflammation controls experienced an improvement in left ventricularEF of $>5 \%(p=0.004)$. The Myocarditis Treatment Trial (MTT) by Mason et al. in 1995 [22] showed neither a benefit nor an increased mortality after a 6-month treatment with cyclosporine A or azathioprine and prednisone when compared with placebo. However, the study was underpowered and did not distinguish viral from nonviral disease, as pointed out in a letter to the editor [23]. In the first 6 months of the immunosuppressive therapy, the MTT showed a trend for the benefit of immunosuppression with respect to transplant-free survival, but it missed statistical significance by one patient. In the later followup, the results remained neutral.

Wojnicz et al. randomized 84 patients with dilated heart muscle disease and increased human leukocyte antigen (HLA) expression for a treatment of azathioprine and prednisone or placebo for 3 months. In the treatment group, EF improved and survival remained comparable between the placebo and verum group [24].

In the TIMIC study, Frustaci et al. reported that the EF of 43 patients in the treatment group improved from $26.5 \%$ at baseline to $45.6 \%$ at 6 months $(p<0.001)$. Similarly, left ventricular end-diastolic volume, left ventricular diameter, and New York Heart Association class improved significantly [25].

The ESETCID (European Study on the Epidemiology and Treatment of Cardiac Inflammatory Disease) is a doubleblind, randomized, placebo-controlled three-armed trial with prednisolone and azathioprine for autoreactive (virus negative) inflammatory dilated cardiomy- 
Table 1 (Continued)

\begin{tabular}{|c|c|c|c|}
\hline & Infectious agent & $\begin{array}{l}\text { \% pos. } \\
\text { in MMR }\end{array}$ & $\begin{array}{l}\text { Comments } \\
\text { Diagnosis made via: }\end{array}$ \\
\hline $\begin{array}{l}\text { 2. Noninfectious } \\
\text { myocarditis }\end{array}$ & Autoreactive myocarditis & 53 & Exclusion of microbial agents \\
\hline \multirow{9}{*}{$\begin{array}{l}\text { Systemic } \\
\text { autoimmune } \\
\text { diseases }\end{array}$} & Giant cell myocarditis & 0.03 & Histology \\
\hline & Wegner's granulomatosis & 0.01 & Histology \\
\hline & Sarcoid heart disease & 0.015 & Histology \\
\hline & Rheumatoid arthritis & 0.03 & Histology and serology \\
\hline & Sjögren syndrome & 0.02 & Serology \\
\hline & Systemic lupus & 0.05 & Serodiagnosis \\
\hline & Crohn's disease & 0.02 & Serodiagnosis \\
\hline & Dermatomyositis & 0.02 & Serodiagnosis \\
\hline & Kawasaki syndrome & 0.015 & - \\
\hline \multirow[t]{2}{*}{ Rejection } & After heart transplantation & 1 & $\begin{array}{l}\text { In cooperation with Hannover } \\
\text { Medical School }\end{array}$ \\
\hline & After stem cell transplantation & 0.002 & - \\
\hline \multirow{2}{*}{$\begin{array}{l}\text { Hypereosinophilic } \\
\text { syndrome (HES) }\end{array}$} & Löffler's endomyocarditis & 0.01 & Biopsy and histology \\
\hline & Churg-Strauss syndrome & 0.01 & Biopsy and histology \\
\hline \multicolumn{4}{|l|}{ 3. Toxicity } \\
\hline Alcohol & Alcoholic cardiomyopathy & 0.2 & $\begin{array}{l}\text { History, negative PCR on } \\
\text { microorganisms }\end{array}$ \\
\hline Drug toxicity & $\begin{array}{l}\text { Aminophylline, amphetamine, } \\
\text { anthracycline, chloramphenicol, } \\
\text { cocaine, cyclophosphamide, } \\
\text { d5-fluorouracil, mesylate, } \\
\text { methyl sergide, phenytoin, } \\
\text { trastuzumab, zidovudine, ipili- } \\
\text { mumab and nivolumab antibod- } \\
\text { ies }\end{array}$ & 0.02 & $\begin{array}{l}\text { Only anthracycline induced } \\
\text { CMP in the MMR }\end{array}$ \\
\hline $\begin{array}{l}\text { Hypersensitivity } \\
\text { reaction (drugs) }\end{array}$ & $\begin{array}{l}\text { Azithromycin, benzodiazepine, } \\
\text { clozapine, cephalosporin, } \\
\text { dobutamine, lithium, diuret- } \\
\text { ics, methyldopa, mexiletine, } \\
\text { streptomycin, sulfonamides, } \\
\text { NSAIDs, tetracycline, tricyclic } \\
\text { antidepressants }\end{array}$ & 0.001 & $\begin{array}{l}\text { Only one patient with lithium } \\
\text { intoxication in MMR }\end{array}$ \\
\hline $\begin{array}{l}\text { Hypersensitivity } \\
\text { reactions (ven- } \\
\text { oms) }\end{array}$ & $\begin{array}{l}\text { Bees, wasps, scorpions, snakes, } \\
\text { spider }\end{array}$ & 0 & - \\
\hline Radiation injury & - & 0.015 & History + biopsy + imaging \\
\hline $\begin{array}{l}\text { Metabolic disor- } \\
\text { der }\end{array}$ & Diabetic cardiomyopathy & 0.02 & $\begin{array}{l}\text { History + biopsy + imaging in } \\
\text { diabetes patients }\end{array}$ \\
\hline $\begin{array}{l}\text { 4. Other DCM } \\
\text { patients }\end{array}$ & - & 16.62 & - \\
\hline \multicolumn{4}{|c|}{$\begin{array}{l}{ }^{2} \text { The MMR included } 1098 \text { patients with the diagnosis of suspected myocarditis or inflammatory } \\
\text { cardiomyopathy who were examined during 1990-2010 (modified from }[1,2,4] \text { ). Diagnoses were } \\
\text { made in most cases via left or right ventricular EMB with PCR, histology, and immunohistology or } \\
\text { conclusive serodiagnosis including cardiac autoantibodies } \\
C M P \text { cardiomyopathy, DCM dilated cardiomyopathy, Echo enteric cytopathic human orphan } \\
\text { virus, EMB endomyocardial biopsy, ELISA enzyme-linked immunosorbent assay, IGRA interfer- } \\
\text { on-gamma-release assay, ISH in situ hybridisation, NSAIDs nonsteroidal anti-inflammatory drugs, } \\
\text { PCR polymerase chain reaction, pos. positive }\end{array}$} \\
\hline
\end{tabular}

opathy in patients with an EF below $45 \%$ at baseline. Interferon alpha is given in enteroviral myocarditis, and intravenous immunoglobulins (ivIg) are given in cytomegalovirus, adenovirus, and parvovirus B19 myocarditis, vs. a placebo drug. The intermediate analysis of the immunosuppressive treatment arm showed a positive trend for EF and major adverse cardiac events after 6 months of treatment and significant benefit after 1 year of follow-up for both groups [26]. Remarkably, the control group also showed also some spontaneous resolution.

\section{Intravenous immunoglobulins}

ivIg have demonstrated benefit in various inflammatory settings, clinically and experimentally. Treatment with ivIg relies on a polypragmatic therapy approach: IvIg interact widely with the immune system. In addition to immunoglobulin G (ivIgG), the IgGAM Pentaglobin ${ }^{\circledR}$, in even lower concentrations than ivIgG, exerts proinflammatory and anti-inflammatory effects. This has been shown in sepsis and also in viral heart disease both clinically and experimentally. Proinflammatory effects are the activation of immune cells and of the complement system and the opsonization of infective agents [27]. Anti-inflammatory effects comprise the neutralization of bacterial and other toxins, of degradation products, and of an excess of complement factors and cytokines. This can stimulate immune cells to set anti-inflammatory cytokines such as interleukin (IL)1RA and IL- 8 free and inhibit the liberation of proinflammatory cytokines, e.g., IL-6 and IL-1 [1]. Anthony et al. [28] have shown that the anti-inflammatory activity of monomeric IgG is completely dependent on the sialylation of the $\mathrm{N}$-linked glycan of the IgG Fc fragment. The IgM fraction in ivIgGAM can play a distinct role in controlling inflammatory and autoimmune disease. Furthermore, IvIgGAM can reduce oxidative stress [29]. Its effect has been shown in heart failure[30-34], in peripartum cardiomyopathy [35], in fulminant [36-38], acute [30,39-46], and chronic myocarditis [38], in dilated cardiomyopathy [46], as well as in enteroviral [47] and in par- 
Main topic

Table 2 Phenotypes of myocarditis and treatment options (modified from [1])

\begin{tabular}{|c|c|c|c|}
\hline Clinical phenotype & Fulminant myocarditis & Acute myocarditis & $\begin{array}{l}\text { Chronic active or persistent myo- } \\
\text { carditis }\end{array}$ \\
\hline Syndrome & $\begin{array}{l}\text { Life-threatening heart failure or rhythm } \\
\text { disturbance }\end{array}$ & $\begin{array}{l}\text { Acute chest wall syndrome or acute on- } \\
\text { set of heart failure; pericardial effusion } \\
\text { (up to } 10 \%) \text {; angina in parvovirus B19 } \\
\text { myocarditis }\end{array}$ & $\begin{array}{l}\text { Chronic heart failure, variable EF with } \\
\text { LV dilatation, } \\
\text { pericardial effusion (up to } 10 \% \text { ); angina } \\
\text { in parvovirus B19 myocarditis }\end{array}$ \\
\hline Dallas criteria [9] & $\begin{array}{l}\text { Infiltrate (active myocarditis or giant } \\
\text { cells), necrosis }\end{array}$ & $\begin{array}{l}\text { Active, often focal lymphocytic myo- } \\
\text { carditis }\end{array}$ & $\begin{array}{l}\text { Borderline myocarditis, focal small } \\
\text { infiltrates }\end{array}$ \\
\hline $\begin{array}{l}\text { World Heart Federa- } \\
\text { tion criteria }[10,11]\end{array}$ & $\begin{array}{l}\geq 50 \text { infiltrating cells } / \mathrm{mm}^{2} \text {, necrosis, } \\
\text { possibly giant cells }\end{array}$ & $\begin{array}{l}\geq 14 \text { infiltrating cells, mostly lympho- } \\
\text { cytes, necrosis, necrosis likely }\end{array}$ & $\begin{array}{l}\geq 14 \text { infiltrating cells, lymphocytes and } \\
\text { macrophages, necrosis and apoptosis } \\
\text { not obligatory }\end{array}$ \\
\hline Immunohistology & $\begin{array}{l}\text { Immunoglobulin binding mostly lgM } \\
\text { to sarcolemma and fibrils and comple- } \\
\text { ment fixation }\end{array}$ & $\begin{array}{l}\text { Immunoglobulin (IgM, IgA and } \operatorname{lgG}) \\
\text { binding to sarcolemma and fibrils }\end{array}$ & $\begin{array}{l}\text { Immunoglobulin (IgG) binding to sar- } \\
\text { colemma and fibrils }\end{array}$ \\
\hline $\begin{array}{l}\text { PCR of microbial } \\
\text { pathogens }\end{array}$ & $\begin{array}{l}\text { Negative in giant cell or autoreactive } \\
\text { myocarditis, positive in up to one third } \\
\text { of cases }\end{array}$ & $\begin{array}{l}\text { Negative in autoreactive lymphocytic } \\
\text { myocarditis, positive in up to one third } \\
\text { of cases }\end{array}$ & $\begin{array}{l}\text { Negative in autoreactive lymphocytic } \\
\text { myocarditis, positive in up to one third } \\
\text { of cases }\end{array}$ \\
\hline Course & $\begin{array}{l}\text { Variable: from fatal outcome to sponta- } \\
\text { neous healing }\end{array}$ & $\begin{array}{l}\text { Variable: from deterioration to defec- } \\
\text { tive healing }\end{array}$ & Chronic heart failure \\
\hline Treatment & $\begin{array}{l}\text { 1. Immunosuppression in PCR-negative } \\
\text { cases, } \\
\text { 2. In virus-positive biopsies; ivlg, } \\
\text { 3. In all patients: assist device and ICDs, } \\
\text { if indicated; heart failure treatment }\end{array}$ & $\begin{array}{l}\text { 1. Immunosuppression in PCR-negative } \\
\text { cases, } \\
\text { 2. In virus-positive biopsies; ivlg, } \\
\text { 3. In all patients: assist device and ICDs, } \\
\text { if indicated; } \\
\text { heart failure treatment }\end{array}$ & $\begin{array}{l}\text { 1. Immunosuppression in PCR-negative } \\
\text { cases, } \\
\text { 2. In viral myocarditis ivlg or } \\
\text { IFN in controlled trials } \\
\text { 3. In all patients: prophylactic ICDs, } \\
\text { when EF < 35\%; } \\
\text { heart failure treatment }\end{array}$ \\
\hline
\end{tabular}

Table 3 Trials on immunosuppressive treatment

\begin{tabular}{|c|c|c|c|c|c|}
\hline Author & Treatment & Endpoint & Patients/controls ( $n$ ) & Result & Comment \\
\hline Parillo et al. [21] & $P$ & $\begin{array}{l}\text { Function + mortality after } \\
3 \text { months }\end{array}$ & $60 / 62$ & Improved $67 \%$ & No viral PCR \\
\hline $\begin{array}{l}\text { Mason et al. (MTT) } \\
{[22]}\end{array}$ & $P+A / C y A$ & Function, mortality & $64 / 47$ & No benefit, no harm & $\begin{array}{l}\text { Underpowered, no viral } \\
\text { PCR }\end{array}$ \\
\hline Wojnicz et al. [24] & $\mathrm{P}+\mathrm{A}$ & $\mathrm{EF}+$ function, mortality & $41 / 43$ & EF improved & No viral PCR \\
\hline $\begin{array}{l}\text { Frustaci et al. (TIMIC) } \\
{[25]}\end{array}$ & $\mathrm{P}+\mathrm{A}$ & $\begin{array}{l}E F+\text { mortality after } \\
6 \text { months }\end{array}$ & $43 / 42$ & $88.3 \%$ improved & $\begin{array}{l}\text { Treatment in virus-neg- } \\
\text { ative pts. only }\end{array}$ \\
\hline $\begin{array}{l}\text { Maisch et al. (ESET- } \\
\text { CID) [26] }\end{array}$ & $\mathrm{P}+\mathrm{A}$ & $\mathrm{EF}+$ function, $\mathrm{MACE}$ & $54 / 47$ & $\begin{array}{l}\mathrm{EF}+\text { function im- } \\
\text { proved after } 2 \text { years }\end{array}$ & $\begin{array}{l}\text { Treatment in virus-neg- } \\
\text { ative pts. only }\end{array}$ \\
\hline
\end{tabular}

vovirus B19-associated heart disease [48, 49]. IgM-enriched immunoglobulins appear to be effective in lower doses [34], which corresponds to our own observation with Pentaglobin ${ }^{\circledR}$. - Table 4 gives an overview of the ivIg studies. Not all studies reported hemodynamic benefit or improvement, however: The IMAC, a randomized controlled trial, demonstrated improvement in both the treatment and placebo arm [42], so that in a recent multi-institutional analysis [50] the benefit in a pediatric population was questioned.
The MMR data support a positive effect of $20 \mathrm{~g}$ i.v. pentaglobin in adenovirus-positive myocarditis for clinical improvement, with eradication of both the inflammation and the virus [51]. In parvovirus B19 myocarditis, our data indicate a clinical improvement; however, only inflammation is successfully eliminated, whereas parvovirus B19 persistence remains a problem in many patients although the viral load is often decreased.

\section{High-dose ivIG in cytomegalovirus myocarditis}

In biopsy-proven cytomegalovirus (CMV) myocarditis, one controlled trial of 18 patients reported on the eradication of inflammation and elimination of the virus [52]. The patients had received $2 \mathrm{ml} / \mathrm{kg}$ i.v. cytomegalovirus hyperimmunoglobulin (CMVhIg) for 3 days and $1 \mathrm{ml} / \mathrm{kg}$ for an additional 2 days, alternately.

In parvovirus B19-associated inflammatory dilated cardiomyopathy, dosefinding studies and randomized trials 
Table 4 Registries and trials with ivlg in inflammatory cardiomyopathy or myocarditis

\begin{tabular}{|c|c|c|c|c|c|}
\hline Authors & Study design & Patients (n) & $\begin{array}{l}\text { Histology } \\
\text { /PCR }\end{array}$ & ivlg dose & Outcome \\
\hline Drucker et al. [40] & Retrospective & 46 children & Partly, no PCR & $2 \mathrm{~g} / \mathrm{kg}$ single dose & Reduced LVEDD \\
\hline $\begin{array}{l}\text { McNamara et al. } \\
\text { [41] }\end{array}$ & Uncontrolled & 10 adults & Partly, no PCR & $2 \mathrm{~g} / \mathrm{kg}$ single dose & Improved EF \\
\hline $\begin{array}{l}\text { McNamara et al. } \\
\text { [42] }\end{array}$ & RCT IMAC & $\begin{array}{l}62 \text { DCM, only } \\
13 \text { myocarditis }\end{array}$ & No PCR & $2 \mathrm{~g} / \mathrm{kg}$ single dose & Both groups improved \\
\hline $\begin{array}{l}\text { Kishimoto et al. [30, } \\
46]\end{array}$ & Case series & $\begin{array}{l}\text { Total 9, } \\
4 \text { myocarditis }\end{array}$ & No PCR & $\begin{array}{l}1-2 \mathrm{~g} / \mathrm{kg} \text { single } \\
\text { dose }\end{array}$ & Improved NYHA and EF \\
\hline Dennert et al. [49] & Uncontrolled & 25 & PVB19 positive & $2 \mathrm{~g} / \mathrm{kg}$ single dose & Decreased viral load, improved EF \\
\hline Maisch et al. [51] & Uncontrolled & $\begin{array}{l}90 \text { PVB19 } \\
36 \text { ADV }\end{array}$ & $\begin{array}{l}\text { PCR-positive for } \\
\text { PVB19 and ADV }\end{array}$ & $\begin{array}{l}20 \mathrm{~g} \text { per person at } \\
\text { day } 1 \text { and } 3\end{array}$ & $\begin{array}{l}\text { Improved EF in } 90 \% \text {, eradication of ADV } \\
\text { in } 90 \% \text {, of inflammation in } 100 \% \text {; PVB19 } \\
\text { eradication in } 40 \% \text {, of inflammation in } \\
70 \%\end{array}$ \\
\hline Maisch et al. [52] & Controlled & $18 / 17$ & CMV by $P C R$ & $\begin{array}{l}14 \text { days, multiple } \\
\text { doses }\end{array}$ & Improved $\mathrm{EF}$, complete $\mathrm{CMV}$ eradication \\
\hline
\end{tabular}

ADV adenovirus, $C M V$ cytomegalovirus, DCM dilated cardiomyopathy, EF ejection fraction, ivlg intravenous immunoglobulins, LVEDD left ventricular end-diastolic diameter, NYHA New York Heart Association, PCR polymerase chain reaction, PVB19 parvovirus B 19

are still lacking and should be planned in the future.

\section{Antiviral treatment with interferon beta}

In the BICC trial, patients with enterovirus-, adenovirus-, and parvovirus $\mathrm{B} 19$-positive genomes received either $4 \times 10^{6}$ or $8 \times 10^{6} \mathrm{IU}$ interferon beta1 bvs. placebo [53]. In the small enteroviral and adenoviral myocarditis strata, interferon-beta tended to eliminate the viral genome, to decrease inflammation, and to improve hemodynamics, whereas in parvovirus B19 and human herpesvirus 6 myocarditis, the response was disappointing. For all three viruses, viral elimination or viral load reduction was higher in the interferon beta- $1 b$ treatment group than in the placebo group, but least effective in the parvovirus B 19 treatment arm.

\section{Practical conclusion}

- In inflammatory dilated cardiomyopathy and myocarditis, apart from heart failure and antiarrhythmic therapies, there is no real alternative to an etiologically driven specific treatment.

- Diagnosis of the underlying microbial agent is a prerequisite for the initiation of treatment with antiviral agents or ivlg, which is the focus of this review.

\section{- If no virus but autoreactive myo- cardial inflammation is identified, immunosuppressive treatment is the treatment of choice.}

\section{Corresponding address}

\section{Prof. Dr. B. Maisch}

Fachbereich Medizin, Philipps-Universität Marburg und Herz- und Gefäßzentrum (HGZ) Marburg

Feldbergstr. 45, 35043 Marburg, Germany bermaisch@gmail.com

Acknowledgements. This work was supported by a grant from the Bundesministerium für Wissenschaft und Forschung (BMBF) in the German Competence Net of Heart Failure (KNHI), by the Prof. Dr. Reinfried Pohl Stiftung, by the Verein zur Förderung der Kardiologie (VFDK) Marburg, and the UKGM Foundation.

\section{Compliance with ethical guidelines}

Conflict of interest. B. Maisch receives honoraria for lectures from Biotest Co. P. Alter declares that he has no competing interests.

This article does not contain any studies with human participants or animals performed by any of the authors.

Open Access This article is distributed under the terms of the Creative Commons Attribution 4.0 International License (http://creativecommons.org/licenses/by/ 4.0/), which permits unrestricted use, distribution, and reproduction in any medium, provided you give appropriate credit to the original author(s) and the source, provide a link to the Creative Commons license, and indicate if changes were made.

\section{References}

1. Maisch B, Pankuweit S (2012) Current treatment options in (peri)myocarditis and inflammatory cardiomyopathy. Herz 37:644-656

2. Caforio AL, Pankuweit S, Arbustini E et al (2013) Currentstate of knowledge on aetiology, diagnosis, management, and therapy of myocarditis: a position statement of the European Society of Cardiology Working Group on Myocardial and Pericardial Diseases. Eur Heart J34(33):2636-2648

3. Pankuweit S, Maisch B (2013) Etiology, diagnosis, management, and treatment of myocarditis. Position paper from the ESC Working Group on Myocardial and Pericardial Diseases. Herz 38:855-861. https://doi.org/10.1007/s00059013-3988-7

4. Maisch B, Pankuweit S (2013) Standard and etiology-directed evendence-based therapies in myocarditis: stat of the art and future perspectives. Heart Fail Rev 18:761-795. https://doi.org/10. 1007/s10741-012-9362-7

5. Alter P, Figiel JH, Rupp TP, Bachmann GF, Maisch B, Rominger MB (2013) MR, CT, and PET imaging in pericardial disease. Heart Fail Rev 306:18-289

6. Maisch B, Ristic AD, Pankuweit S (2017) Inflammatorische Kardiomyopathie und Myokarditis. Herz 42:425-438. https://doi.org/10.1007/s00059017-4569-y

7. Maisch B, Alter P, Pankuweit S (2011) Diabetic cardiomyopathy -fact or fiction? Herz 36:102-115

8. Maisch B (2016) Alcoholic cardiomyopathy: the result of dosage and individual predisposition. Herz 41:484-493. https://doi.org/10.1007/ s00059-016-4469-6

9. Aretz HT, Billingham M, Olsen E et al (1987) Myocarditis: the Dallas criteria. Hum Pathol 18:619-624

10. Maisch B, Bültman B, Factor S et al (1999) World Heart Federation consensus conference's definition of inflammatory cardiomyopathy (myocarditis): report from two expert committees on histology and viral cardiomyopathy. Heartbeat 4:3-4

11. Maisch B, Portig I, Ristic A et al (2000) Definition of inflammatory cardiomyopathy (myocarditis): on the way to consensus. Herz 25:200-209 
12. Costanzo-Nordin MR, Reap EA, Robinson JA, ScanIon PJ (1985) A nonsteroid anti-inflammatory drug exacerbates Coxsackie B3 murine myocarditis. J Am Coll Cardiol 6:1078-1082

13. Maisch B, Ristic AD, Seferovic PM, Tsang TSM (2011) Interventional pericardiology. Pericardiocentesis, pericardioscopy, pericardial biopsy, balloon pericardiotomy and intrapericardial therapy. Springer, Heidelberg

14. Amiodarone Trials Meta-Analysis Investigators (1997) Effect of prophylactic amiodarone on mortality after acute myocardial infarction and in congestive heart failure: meta-analysis of individual data from 6500 patients in randomized trials. Lancet 350:1417-1424

15. Bardy GH, Lee KL, Mark DB et al (2005) Amiodarone or an implantable cardioverterdefibrillator for congestive heartfailure. NEngl JMed 352:225-237

16. Hunt SA, Abraham WT, Chin MH et al (2009) 2009 Fucussed update incorporated into the ACC/AHA 2005 Guidelines for the diagnosis and management of heart failure in adults. J Am Coll Cardiol 53:e31-e90 (A report of the American College of Cardiology Foundation/American Heart Association Task Force on Practice Guidelines developed in collaboration with the International Society for Heart and Lung Transplantation)

17. Cooper LT, Berry GJ, Shabetai R (1997) Idiopathic giant cell myocarditis-natural history and treatment. NEngl J Med 336:1860-1866

18. Bargout R, Kelly RF (2004) Sarcoid heart disease. Clinical course and treatment. Int J Cardiol 97:173-182

19. Tai PC, Ackerman SJ, Spry CJ et al (1987) Deposits of eosinophil granule proteins in cardiac tissues of patients with eosinophilic endomyocardial disease. Lancet 1(8534):643-647

20. Maisch B, Baandrup U, Moll R, Pankuweit $S$ (2009) Eosinophilic carditis is rare but not to be overlooked. Eur Heart J 30(Suppl1). https://doi. org/10.1093/eurheart/ehp413

21. Parillo JE, Cunnion RE, Epstein SE et al (1989) A prospective, randomized, controlled trial of prednisone for dilated cardiomyopathy. N Engl J Med 321:1061-1068

22. Mason JW, O'Connel JB, Hershkowitz A et al (1995) A clinical trial of immunosuppressive therapy for myocarditis. The Myocarditis Treatment Trial Investigators. N Engl JMed 33:269-275

23. Maisch B, Camerini F, Schultheiss H-P (1995) Immunosuppressive therapy for myocarditis (letter). N Engl J Med 333:1713

24. Wojnicz R, Nowalany-Koziolaska E, Wojciechowska C et al (2001) Randomized, placebo-controlled study for immunosuppressive treatment of inflammatory dilated cardiomyopathy. Two-year follow-up results. Circulation 104:39-45

25. Frustaci A, Russo MA, Chimenti C (2009) Randomized study on the efficacy of immunosuppressive therapy in patients with virus-negative inflammatory cardiomyopathy: the TIMIC study. Eur Heart J 30:1995-2002

26. Maisch B, Kölsch S, Hufnagel G et al (2011) Resolution of Inflammation determines short-and longterm prognosis in myocarditis in ESETCID. Circulation 124(21 Suppl):A15036

27. Nimmerjahn F, Ravetsch JV (2008) Anti-inflammatory actions of intravenous immunoglobulin. Annu Rev Immunol 26:513-533

28. Anthony RM, Nimmerjahn F, Ashline DJ et al (2008) Recapitulation of IVIG anti-inflammatory activity with a recombinant Ig Fc. Science 320:373-376

29. Grönwall C, Silverman GJ (2014) Natural IgM: Beneficial autoantibodies for the control of inflammatory and autoimmune disease? J Clin Immunol 34(1):S12-S21

30. Kishimoto C, Shioji K, Kinoshita M et al (2003) Treatment of acute inflammatory cardiomyopathy with intravenous immunoglobulin ameliorates left ventricularfunction associated with suppression of inflammatory cytokines and decreased oxidative stress. Int J Cardiol 91:173-178

31. Gullestad L, Aass H, Fjeld JG et al (2001) Immunomodulating therapy with intravenous immunoglobulin in patients with chronic heart failure. Circulation 103:220-225

32. Aukrust P, Yndestad A, Ueland Tet al (2006) The role of intravenous immunoglobulin in the treatment of chronic heart failure. Int J Cardiol 112(1):40-45

33. Udi N, Yehuda S (2008) Intravenous immunoglobulin-indications and mechanisms in cardiovascular diseases. Autoimmun Rev 7(6):445-452

34. Walpen AJ, Laumonier T, Aebi C et al (2004) $\lg \mathrm{M}$ enriched intravenous immunoglobulin inhibits classical pathway complement activation but not bacterial killing by human serum. Xenotransplantation 11(2):141-148

35. Bozkurt B, Villaneuva FS, Holubkov R et al (1999) Intravenous immune globulin in the therapy of peripartum cardiomyopathy. J Am Coll Cardiol 34:177-180

36. Takeda Y, Yasuda S, Miyazaki S et al (1998) Highdose immunoglobulin $\mathrm{G}$ therapy for fulminant myocarditis. Jpn Circ J 62:871-872

37. Goland S, Czer LSC, Siegel RJ et al (2008) Intravenous immunoglobulin treatment for acute fulminant inflammatory cardiomyopathy: series of sixpatients and review of literature. Can J Cardiol 24(7):571-574

38. Shioji K, Matsuura Y, Iwase T et al (2002) Successful immunoglobulin treatment for fulminant myocarditis and serial analysis of serum thiredoxin-a case report. Circ J66:977-980

39. Robinson J, Hartling L, Crumley E et al (2005) A systematic review of intravenous gamma globulin for the therapy of acute myocarditis. BMC Cardiovasc Disord 5:12-18

40. DruckerNA, Colan SD, Lewis AB etal (1994) Gammaglobulin treatment of acute myocarditis in the pediatric population. Circulation 89:252-257

41. McNamara DM, Rosenblum WD, Janosko KM et al (1997) Intravenous immune gobulin in the therapy of myocarditis and acute cardiomyopathy. Circulation 95:2476-2478

42. Intervention in Myocarditis and Acute Cardiomyopathy (IMAC) Investigators, McNamara DM, Holubkov R, Starling RC et al (2001) Controlled trial of intravenous immune globuline in recent-onset dilated cardiomyopathy. Circulation 103:2254-2259

43. Tedeschi A, Liraghi L, Giannini S et al (2002) High-dose intravenous immunoglobulin in the treatment of acute myocarditis. A case report and review of the literature. J Intern Med 251:169-173

44. Tsai YG, Ou TY, Wang CC et al (2001) Intravenous gamma-globulin therapy in myocarditis complicated with complete heart block: report of one case. Acta Paediatr Taiwan 42(5):311-313

45. Shioji K, Kishimoto C, Sasyama S (2000) Immunoglobulin therapy for acute myocarditis Respir Circ 48(11):1133-1139

46. Kishimoto C, Fujita M, Kinoshita M et al (1999) Immunglobulin therapy for myocarditis an acute dilated cardiomyopathy. Circulation 100(18):1405-1408

47. Takada H, Kishimoto C, Hiraoka Y (1995) Therapy with immunoglobulin suppresses myocarditis in a murine coxsackievirus B3 model-antiviral and anti-inflammatory effects. Circulation 92(6):1604-1611

48. Selbing A, Josefsson A, Dahle LO, Lindgren R (1995) Parvovirus B19 infection during pregnancy treated with high-dose intravenous gammaglobulin. Lancet 345:660-661

49. Dennert R, Velthuis S, Schalla S et al (2010) Intravenous immunoglobulin therapy for patients with idiopathic cardiomyoapthy and endomyocardial biopsy-proven high PVB19 viral load. Antivir Ther 15:193-201

50. Klugman D, Berger JT,SableCA etal (2009) Pediatric patients hospitalized with myocarditis: a multiinstitutional analysis. Pediatr Cardiol 31:222-228

51. Maisch B, Haake $H$, Schlotmann N, Pankuweit $S$ (2007) Abstract 1616: intermediate dose of pentaglobin eradicates effectively inflammation in parvo B19 and adenovirus positive myocarditis. Circulation 116:II_338

52. Maisch B, Pankuweit S, Funck R, Koelsch S (2004) Effective CMV hyperimmunoglobulin treatment in CMV myocarditis - a controled treatment trial. Eur Heart JSuppl 114:P674

53. Schultheiss H-P, Piper C, Sowade O et al (2016) Betaferon in chronic viral cardiomyopathy(BICC) trial: Effect of interferon-ß treatment in patients with chronic viral cardiomyopathy. Clin Res Cardiol 105(9):763-773 